\title{
The effect of brand image, brand trust and reference group on the buying decision of sneakers
}

Miswanto Miswanto $^{1^{*}}$, Rijal Rizki Mubarok ${ }^{2}$, Nikodemus Hans Setiadi Wijaya ${ }^{3}$

Sekolah Tinggi Ilmu Ekonomi (STIE) YKPN Yogyakarta, Indonesia ${ }^{1,2,3}$

miswanto.ykpn@gmail.com

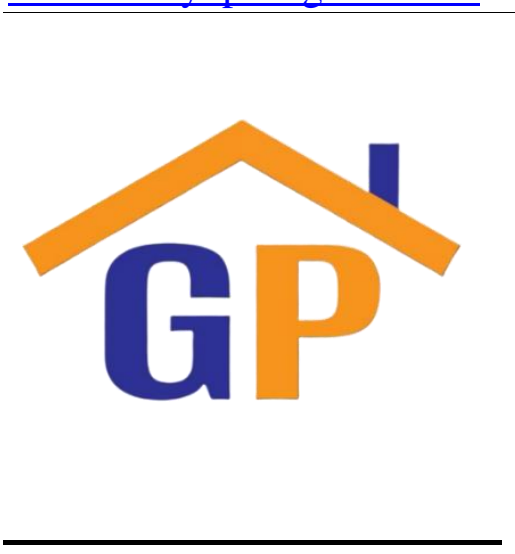

Article History

Received on 4 July 2020

$1^{\text {st }}$ Revision on 29 October 2020

$2^{\text {nd }}$ Revision on 4 November 2020

Accepted on 5 November 2020

\begin{abstract}
Purpose: The purpose of conducting this study was to test the effect of brand image, brand trust, and reference group on buying decision of sneakers.
\end{abstract}

Research methodology: This study took the primary data through questionnaires distribution. The analytical method used is multiple-linear regression.

Results: The finding from hypothesis testing results is that brand image, brand trust, and reference group have positive effect on buying decision of sneaker shoes.

Limitations: The testing involved only 3 factors, while generally, buying decision is often affected by some other factors for example, price, taste, and others.

Contribution: This study can be used to add insight and reference for the next study, especially in the marketing of sneakers.

Keywords: Brand image, Brand trust, Reference group, Sneakers

How to cite: Miswanto, M., Mubarok, R., Wijaya, N. H. S. (2019). The effect of brand image, brand trust and reference group on the buying decision of sneakers. International Journal of Financial, Accounting, and Management, 1(2), 105-118.

\section{Introduction}

Fashion is a symbol of a person and it cannot be separated from history and human's life (Fakhrunnisa, 2016). Fashion can be said as appearance of social aspect containing message and how to dress of individual or certain group as a sub-system of social cultural system. In this era, many phenomena of young people follow the development of fashion trends and the changing of times. This can be because it is easy to access social media that allows people to see, search reference, or shop easily. When looking for reference in fashion, most young people usually see the reference from various sources, whether from a rising trend, price consideration, and some who only buy without looking at the happening trend.

Over time, fashion trend is varied in shirts and pants and shoes as their complement. Shoes consist of many kinds, starting from casual, formal, sport, to sneakers. Sneakers are the shoes with elastic sole material made of rubber, or other elastic materials and the upper parts are made of leather or canvas materials. There are many sneakers popular brands such as Converse, Vans, Adidas, Nike, and others in Indonesia. Sneaker users in Indonesia are 
increasing from year to year. Sneakers enthusiasts are more realistic. They are aware of education for not buying counterfeit products but buying original and qualified products. Another thing that makes sneakers more popular is the variety of newest models and collaborations among the brands with artists who usually create unique and limited products (Hasibuan, 2018).

The phenomena that make sneakers increasingly popular among young people are also because of the reference group's effect. Among young people in Indonesia, many idols become role models known as influencers. An influencer is a person who has many followers and audiences in social media, and he/she has a strong influence on the followers. A review article from the website "BukaReview" entitled "In-depth: Shopping Interest is Affected by Instagram Fashion Influencer" discussed that after a study involving 51 respondents was done, the reason for product buying decision is because they looked for reference initially through social media and absolutely the one promoted by an influencer, and it is driven with the reason when the influencer has used the product, the product is better (Nainggolan, 2018). Based on the phenomena followed by the above data, the researcher is interested in choosing three variables affecting consumers' decision in buying sneakers, which are brand image, brand trust, and the reference group.

Research from Sulistyawati (2011), Arista \& Astuti (2011), and Bintang Anoraga \& Iriani (2014) indicate that in Indonesia, there have been several studies on the influence of a brand image, trust brand, and reference groups on consumer purchasing decisions. However, there is no such research with research decisions on sneakers. So the novelty of this research lies in the product to be studied.

Brand image refers to memory on a brand, containing of consumer's understanding on uniqueness, model, form, user, and the brand alone in marketing its product (Setiadi, 2003). An example of the phenomenon of brand image effect in Indonesia is the out of the Compass shoes Bravo series in 1.5 hours after being released on Jakarta Sneakers Day. The consumers flocked and were willing to queue to get the latest released shoes that are unique and limited sold. It can be related to the effect of brand image because, according to the statement, most Compass consumers feel dashing if they could get the limited edition shows.

Brand trust is an illustration or perception of consumers who trust and is based on the experience initiated from pre-buying to post-buying and is followed by product performance satisfaction (Rizan, 2012). In other words, to obtain brand trust, the quality and position of a brand are needed in the community in order to be able to generate trust and ended with a buying decision on the brand.

A reference group is an individual or a group of people who are able to affect the character and style of someone (Sumarwan, 2014). In other words, a reference group is someone's instrument in comparing choice or reference in interest, taste, as well as in behavior. The reference group usually makes a certain parameter or styles that will be followed by someone. In marketing, reference group plays as a consideration or example when a consumer conducts product buying process. In late 2018, manufacturing shoes, Ardiles, received outstanding response because of selling 300 pairs of shoes with model 'AZA 6' in 
11 hours. It was because President Jokowi was seen wearing those shoes (Susanti, 2018). This phenomenon shows that someone who affects community also affects buying decisions because generally, what is done by public figures will draw attention to community.

In this study, the researcher tries to explore the phenomena how sneakers became very popular in the millennials in big cities, especially in Yogyakarta, as well as to investigate the relationship of brand image, brand trust, and reference group in determining the purchase of sneakers. Based on the explanation above, the problems in this study are explained as the following. First, whether brand image has effect on buying decision of sneakers. Second, whether brand trust has effect on buying decision of sneakers. Third, whether reference group has effect on buying decision of sneakers.

The motivations to conduct this study are as the following. The first is to examine whether brand image have effect on buying decision of sneakers. The second is to examine whether brand trust has effect on buying decision of sneakers. The third is to examine whether reference group has effect on buying decision of sneakers. The benefit of this study is expected to be reference sources of the following. First, it can give insight and make this study as the reference for the next study, especially in marketing of sneakers. Second, it can be information source for producer in creating a model or design of sneakers up to promoting the sneakers. Third, it can be the insight for the next researchers in marketing, especially in sneakers. .

\section{Literature review and hypotheses development}

Literature review that will be described is related to the variables that will be studied. The description is started from brand image, brand trust, reference group, and buying decision.

\subsection{Brand image}

Brand image is a name or specialty that is the business unit's identity to distinguish from other goods or services (Kotler \& Keller, 2006). Brand image refers to memory of a brand containing consumer's understanding of uniqueness, model, form, user, and the way of the brand alone in marketing its products. If the consumer's perception is positive toward a certain brand, it will stimulate consumers and users to carry out a buying decision. Referring to Kotler \& Keller (2006), brand has a number of benefits, among others are: a) Brand is used as the means of knowing the product origin from its seller, b) brand is used in an attempt in reducing risks, c) Brand is used as the characteristics and specialty that become differentiator in brands competition, and d) brand is a reflection of quality of an company.

The indicator of brand image can be measured in many ways. Referring to the theory stated by Biel (1992) and Engel, Roger \& Paul (1995) in Ain \& Ratnasari (2015), there are several indicators to measure brand image among others: a) corporate image, b) user image, c) product image, and d) store image. Kotler (2003) stated that brand image could be measured. Referring to an aspect of a brand, there are some points for measuring a brand, among others are: a) strength, b) uniqueness, and c) favorable. Those are the product brand excellence that can be remembered by consumers or customers; the ability to be recognized makes a brand to be favourite among the community. This brand excellence can be shown if there is a similarity between customer's positive impressions and company goals. 


\subsection{Brand trust}

Brand trust is the perception of consumers who believe that when conducting transaction, they end on post-buying satisfaction (Rizan, 2012). Then, according to Delgado-Ballester, Munuera-Aleman \& Yague-Guillen (2003), brand trust is defined as consumer's secured attitude because they already have trusted to a brand. According to Lau \& Lee (1999), brand trust is someone's attitude position when they are surely satisfied when they expect a certain product. That can be the conclusion that brand trust is someone's wish in believing without any doubt toward a brand because the trust is able to give positive effect, and eventually it will create satisfaction after buying.

Delgado-Ballester \& Munuera-Alemán (2001) stated that the things affecting brand trust can be brand reliability and brand intentions. The following indicators of brand trust are also described by Lau \& Lee (1999). Their description became the parameter of trust toward brand, and in its description, there are matters as the following. The first is brand characteristics. When consumers conduct buying decisions, the important role is by searching brand's details because generally someone will first evaluate a brand before conducting buying. There are several characteristics related to brand, such as: a) brand reputation, b) brand predictability, and d) brand competence. The second is corporate characteristics. Few things from corporate characteristics can affect someone's trust toward a brand, among others are: a) trust toward company, b) reputation on company, c) customers who feel the motif of company, and d) company's integrity. The third or the last is characteristics of brand with consumer. The characteristics of brand and consumer are a) similarity between consumer's nature and brand characteristics, b) brand enjoyment, c) brand experience, d) brand satisfaction, and e) group influence.

\subsection{Reference group}

Reference group often becomes consideration of someone in deciding to buy goods or services. Reference group functionates as information sources or examples for consumers when making decision toward buying. According to Sumarwan (2014), the types of reference groups are: a) formal group, b) informal group, c) aspiration group, and d) dissociation group. Moreover, there are types of references according to the statement of Schiffman \& Kanuk (2007). The types of groups are: a) friendship group, b) shopping group, c) working group, and d) netizen group.

\subsection{Buying decision}

The above description is the factors or variables affecting decision done by consumers to buy things. The buying decision is consumer's action after conducting some steps until the last is buying a thing or service from a company. Consumers are affected by some factors in determining the buying such as quality, price, brand, company's image, and place. Kotler (2003) stated that buying decision is defined after some steps before buying. Decision making has some levels. Amirullah (2002) stated that the levels of decision making consist of a) extended problem solving, b) limited problem solving, and c) routine problem solving.

Regarding to the above explanation, the following is the hypothesis developed in this study. $\underline{\text { Romadhoni (2015) }}$ stated that brand image had positive effect on buying decision of Nike 
shoes among students at FIK UNY. Some studies such as the study of Suciningtyas (2012) stated the buying of motorbike Yamaha Mio Sporty at one dealer in Brebes was affected by brand image. In the field study, consumers generally make buying decisions quickly when faced by some choices that have similar function, so brand image has an important role as a driving factor in buying decisions. The study from Sulistyawati (2011) stated brand image as consumer's final input in buying decision making of laptop Acer. Referring to the above description, the hypothesis that can be formulated is stated as the following:

H1: Brand image has positive effect toward decision making.

Adiwidjaja \& Tarigan (2017) found that the buying Converse shoes was affected by image and brand trust of those shoes. The following study from Pratama, Nugraha, \& Suryoko (2014) stated that buying decision of Anlene milk was affected significantly by its brand trust. In the study of Arista \& Astuti (2011) proved that consumer's trust toward internet provider Telkom Speedy because of some factors among others were service satisfaction and quality. Therefore, trust toward brand can be serious in the buying decision. From the above description, the hypothesis can be formulated as the following:

H2: Brand Trust has positive effect on buying decision.

Fitriyah (2013) found that buying handmade batik is affected positively by reference group. Some following studies from Anoraga \& Iriani (2014) stated that buying decision of smartphone Samsung Galaxy was affected by reference group and lifestyle. It supported that reference group is actually someone's motivation in buying. From the above description, the hypothesis can be stated as the following:

H3: Reference group has positive effect on buying decision.

Referring to the description, the model of the study can be illustrated as the following:

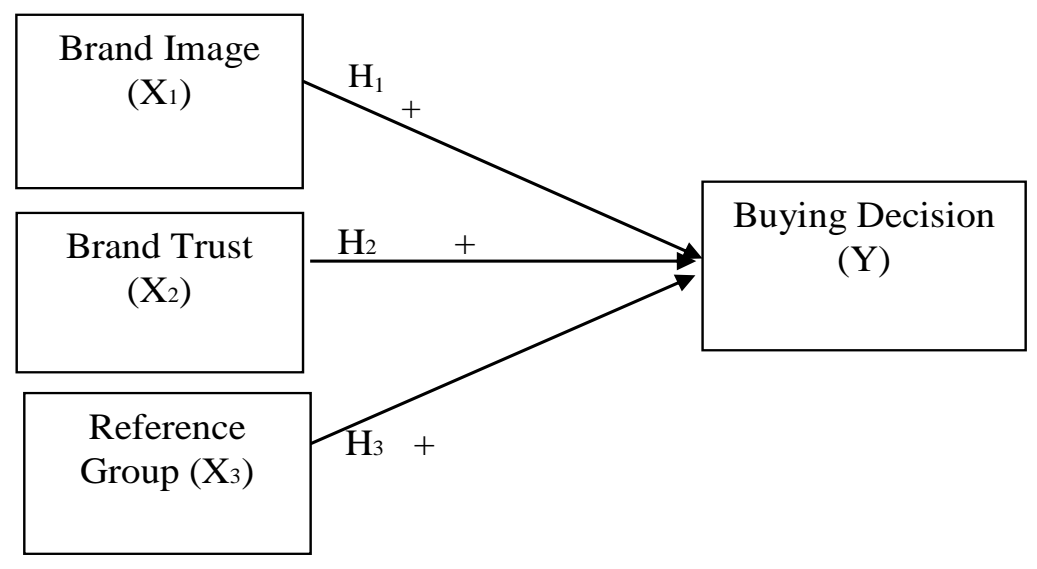

Figure 1 Model of Study 


\section{Research methodology}

This study used quantitative approach in the form causal assosiative. According to $\underline{\text { Sugiyono }}$ (2013), a causal assosiative study aims to examine the effect between two or more variables to describe and solve a problem. This study was held in Yogyakarta, especially skateboarding community, clothing stores, sneakers stores, and cafes used for gathering sneakers lover community. This study was conducted in January 2019.

The respondents in this study were young people and adults in Yogyakarta especially sneakers lover community. Meanwhile, the sampling method in this study was purposive sampling. Data used in this research are quantitative obtained from the field directly or primary data.

This study used independent variable and dependent variable. Its independent variables consist of Brand Image (X1), Brand Trust (X2), and Reference Group (X3). Its dependent variable is buying decision of sneakers $(\mathrm{Y})$. The variable operational definitions are as the following. Brand Image (X1) means a name, uniqueness, or the combination of both that becomes the identity of a business unit to distinguish the product from other products (Kotler \& Keller, 2006). Brand Trust (X2) is the perception of consumer who trust on experience, or has made transaction and it is followed by satisfaction of product performance (Rizan, 2012). Reference Group (X3) is someone or a group of people who try to influence behavior and style and followed by others (Sumarwan, 2014). The concept and indicators for each variable are presented on Table 1.

Primary data collected used research instrument. The instrument is in the form of list of questions that is made based on variable operational definition used in the study. The available answer alternative is based on Likert Scale. The scale is 5 answer alternatives which are: (1) SS/SA (Strongly Agree) that has value of 5, (2) S/A (Agree) that has the value of 4, (3) N (Normal) that has the value of 3, (4) TS/D (Disagree) that has the value of 2, and the last (5) STS/SD (strongly disagree) that has the value of 1 (Simamora, 2005).

The research instrument testing uses validity test and reliability test. The validity test is data accuracy level obtained from research object and the data reported by the researcher. The research instrument can be valid if the answers on the variable are given carefully. It can be proven how accurate the statement is, whether it is expressed according to validity coefficient. The analysis used to test the validity of each item of question in the instrument is Pearson Corellation. In calculating the value of correlation, the researcher used SPSS Version 2.1. The result is stated valid if $r$ count $>r$ table (Ghozali, 2011).

Besides valid, data must be reliable. Reliability test is related to estimation of a measurement that can be seen from information consistency and stability or answers or questions. If the measurement is repeatedly used and the obtained answers relatively consistent, the measurement is considered reliable. Reliability test explains how far the data able to give answer relatively similar if the measurement is done again with similar object. The reliability 
measurement of questionnaire used Cronbach Alpha coefficient with the signifance level of $5 \%$. In the calculation, the researcher used SPSS Version 2.1 with the reliable provision of Cronbach Alpha > 0.6 (Ghozali, 2011).

Before conducting hypothesis test, descriptive analysis toward the collected data was done. Hypothesis of this study used multiple linear regression with regression model ordinary least square (OLS). The software used to analyse was IBM SPSS Version 2.4. The steps in hypothesis testing are classic assumption test, $\mathrm{t}$ test, determination test, and simultaneous test. Equation model of multiple linear regression is as the following:

$$
\mathrm{Y}=\beta_{0}+\beta_{1} \mathrm{X} 1+\beta_{2} \mathrm{X} 2+\beta \mathrm{X} 3+\mathrm{e} \ldots .(1)
$$

With t test, $\mathrm{H} 1, \mathrm{H} 2$, and $\mathrm{H} 3$ were supported if statistically it regression coefficient is greater than zero.

Table 1. Concept and Indicator of Study Variable

\begin{tabular}{|c|c|c|}
\hline Variable & Concept & Indicator \\
\hline $\begin{array}{l}\text { Brand } \\
\text { Image } \\
(\mathrm{X} 1)\end{array}$ & $\begin{array}{l}\text { Brand Image is a name, symbol, } \\
\text { mark, or design, or the combination } \\
\text { of some used as a business unit's } \\
\text { identity to distinguish from other } \\
\text { goods or services. }\end{array}$ & $\begin{array}{l}\text { 1. Company's image } \\
\text { 2. User image } \\
\text { 3. Product image } \\
\text { 4. Store image }\end{array}$ \\
\hline $\begin{array}{l}\text { Brand } \\
\text { Trust (X2) }\end{array}$ & $\begin{array}{l}\text { Brand trust is a perception of } \\
\text { consumers who believe and have } \\
\text { conducted transaction and followed } \\
\text { to product performance satisfaction. }\end{array}$ & $\begin{array}{l}\text { 1. Characteristics of brand } \\
\text { consist of brand reputation, } \\
\text { brand predictability, and } \\
\text { brand competence. } \\
\text { 2. Characteristics of company } \\
\text { consist of trust on reputation, } \\
\text { motive, and integrity of } \\
\text { company. } \\
\text { 3. The characteristics of brand } \\
\text { consumers consist of taste } \\
\text { comformity of someone } \\
\text { toward brand characteristics } \\
\text { such as fondness, experience, } \\
\text { satisfaction, and others' } \\
\text { influence. }\end{array}$ \\
\hline $\begin{array}{l}\text { Reference } \\
\text { Group } \\
\text { (X3) }\end{array}$ & $\begin{array}{l}\text { Reference group is someone's } \\
\text { instrument in comparing reference or } \\
\text { as parameter in behavior. }\end{array}$ & $\begin{array}{l}\text { 1. Normative } \\
\text { a. Using brand because of } \\
\text { many users. } \\
\text { b. To synchronize } \\
\text { similarity to friends. } \\
\text { c. Using brand because of } \\
\text { suggestion from friends. }\end{array}$ \\
\hline
\end{tabular}


2. Informational

a. Listening to brand's features from friends.

b. Avoiding dissatisfaction.

c. Assured by friends.

d. Confidence in

environment increases

\begin{tabular}{llll}
\hline Buying & Buying decision is defined as various & 1. Extended problem solving. \\
Decision & steps undergone by consumers & 2. Limited problem solving \\
(Y) & before buying. & 3. Routine problem solving
\end{tabular}

Sources: Lau \& Lee (1999), Amirullah (2002), Ain \& Ratna (2015), and Sumarwan (2014).

\section{Results and discussions}

This study was conducted in January 2020 with the targeted consumers of sneakers in Yogyakarta including students or workers especially sneakers lovers. In this study, the researcher obtained 125 respondents by using purposive sampling method. From the respondents' collected data, the sneakers brands consisted of Vans, Converse, Nike, Sketchers, Reebok, Macbeth, and Compass. The following is the data of sample distribution percentage based on sneakers users. The users of Vans obtained the largest percentage which was $30 \%$. The users Converse and Nike were on the second, with percentage of $22 \%$. The users of Sketchers was 6\%. The users of Compass was 3\%. The users of Reebok and Macbeth obtained similar percentage which was $2 \%$. The rest of $4 \%$ was the users of other brands that were not mentioned.

Based on the demographic analysis result, the studied respondent distribution is as the following. Male respondents were $66 \%$ and $34 \%$ was female respondents. Based on the age, respondents below 20 years old were 13\%, 20-25 years old were 79\%, 26-30 years old were $7 \%$, and above 30 years were $1 \%$. Based on the job, students were $60 \%$, employees were $22 \%$, entrepreneurs were $9 \%$, and the rest of $9 \%$ were not in the above categories.

Before being analized further, the collected data was tested for their validity and reability. Validity test aims to analyze the level the level of validity of a questionnaire. In this study, the researcher tested the validity of data by using pearson correlation method. The validity testing result can be said valid when the value of $r$ count more than $r$ table, while with 125 respondents, $\mathrm{r}$ table was 0.175 . The instrument of questions for Brand Image are as the following. B1: I wear sneakers because of the company's image; B2: I choose the brand because it is famous; B3: Many people know the brand of the sneakers I buy; B4: The sneakers I wear make me look cool; B5: I use sneakers because the model is interesting; and B6: Sneakers I wear are in accordance with the present trend; B7: I buy sneakers from trusted store; B8: I usually choose sneakers at certain stores that are famous for selling original products, and B9: I like certain sneakers stores because their services are good. In Brand Image, all $r$ count in all questions are more than $r$ table. Based on that, all questions to measure Brand Image are valid. 
The instrument of questions for Brand Trust (BT) as the following. BT1: I believe that the sneakers I wear have good quality; BT2: I think the sneakers I wear have trendy model; BT3: the brand of the sneakers I choose is always competent in making the product; BT4: I believe every product released by the brand of my favourite sneakers is always good; BT5: the brand of my favourite sneakers has good reputation in shoes world; BT6: the sneakers I wear reflect my personality; B7: I wear sneakers with certain brand because in the past I had the same brand; B8: I feel satisfied when having sneakers I want; and B9: My friends are happy when I have new sneakers. In Brand Trust, all $r$ count on all questions are more than $r$ table. Therefore, all question instruments for measuring Brand Trust are valid.

The instrument of questions for Reference Group (RG) are as the following. RG1: I use the brand because many people use them; RG2: I wear sneakers for adjusting to the trend among friends and environment; RG3: I choose certain brand or model because I do not want to disappoint my friend's choice; RG4: My friends suggested me various sneakers brands; RG5: I choose certain brand to avoid the risk of dissatisfaction to the friends who have bought them; RG6: I choose certain brand of sneakers because others convince me; and RG7: Sneakers I wear increase my self-confidence when gathering with friends. In Reference Group, all $r$ count in all questions are more than $r$ table. Therefore, all question instruments for measuring Reference Group are valid.

Question instruments for Buying Decision (BD) are as the following: BD1: When buying sneakers I usually check on the catalogue on social media, websites, and others; BD2: I tend to search the materials I want (for example canvas, suede, and other); BD3: I try to evaluate the product of sneackers in market: BD4: before buying, I like to compare the brand of the sneakers with other brands: BD5: I usually compare one sneakers brand to other brands; BD6: I pay attention to the materials between one product to another before buying sneakers; BD7: I get bored with certain brand and suddenly want to buy different brand; and BD8: at the sneakers store I usually only compare the price. In Buying Decision, all $r$ count in all questions are more than $\mathrm{r}$ table. Therefore, all question instruments for measuring Buying Decision are valid.

The next test is reliability test. Reliability test aims to test how far a measurement can be reliable, in this study, the researcher tested it by using Pearson method cronbach alpha $>0.60$. The result of reliability test on four research variables are as the following. The value of Cronbach's Alpha on variable Brand Image, Brand Trust, Reference Group, and Buying Decision are 0.870, 0.873, 0.792, and 0.849. All Cronbach's Alpha values are more than 0.6. Therefore, all question instrument on those variables are can be reliable.

After conducting validity test and reliability test, the next step is conducting classic assumption test. Classic assumption tests done are normality, multicollinearity, heteroskedasticity, and linearity tests. The testing result shows that the data used pass from those classic assumption tests. Therefore, its regression estimation is BLUE (Best Linear Unbiased Estimator).

Before the hypothesis test, the step done is descriptive analysis. The results of descriptive analysis of the dependent variable and independent variable are as the following. Variable 
Brand Image had an average of 4.01. The value was more than its middle value. It means that the respondents tended to agree that sneakers have brand image. Variable Brand Trust had a total average of 3.91. The value was more than its middle value. It indicates that the respondents tended to agree that sneakers have Brand Trust. Variable Reference Group had the average of 3.37. The value was more than its middle value. It indicates that the respondents tended to agree that sneakers have Reference Group. The variable sneakers Buying Decision had the average of 3.95. The value was more than its middle value. It indicates that the respondents tended to agree to buy sneakers. Therefore, based on the descriptive analysis, the respondents generally agreed that the sneaker products have a brand image, brand trust, and reference group. Moreover, the respondents tended to agree to buy sneakers.

In this study, hypothesis testing used multiple linear regression analysis models including $\mathrm{t}$ statistic test, $\mathrm{F}$ test, and determination coefficient test. The result of multiple linear regression analysis can be viewed on the table below:

Table 2. The Result of Multiple Linear Regression Test

\begin{tabular}{|c|c|c|c|c|c|c|}
\hline \multirow[t]{2}{*}{ Variable } & \multirow{2}{*}{$\begin{array}{l}\text { Coefficient } \\
\text { Regression }\end{array}$} & \multirow{2}{*}{$\begin{array}{l}\text { T count } \\
\text { value }\end{array}$} & \multirow[t]{2}{*}{ Sig } & \multirow{2}{*}{$\begin{array}{l}\text { Adjusted } \\
R \text { square }\end{array}$} & \multicolumn{2}{|c|}{ F Test } \\
\hline & & & & & $\begin{array}{c}\mathrm{F} \\
\text { Count }\end{array}$ & Sig. \\
\hline Constant & 7.671 & 3.011 & 0.003 & 0.415 & 30.365 & 0.000 \\
\hline Brand Image (X1) & 0.185 & 2.382 & 0.019 & & & \\
\hline Brand Trust (X2) & 0.375 & 3.781 & 0.000 & & & \\
\hline $\begin{array}{l}\text { Reference Group } \\
\text { (X3) }\end{array}$ & 0.218 & 2.413 & 0.017 & & & \\
\hline
\end{tabular}

Source: Data from respondents processed using SPSS.

Based on Table 2 above, the estimation result of multiple linear regression could form the regression equation as the following:

$$
\mathrm{Y}=7,671+0,185 \mathrm{X} 1+0,375 \mathrm{X} 2+0,218 \mathrm{X} 3+\mathrm{e}
$$

From the regression equation above, there some matters that can be explained as the following. The Constant above is 7.671, in other words, if the value of each independent which is $\mathrm{X} 1, \mathrm{X} 2, \mathrm{X} 3, \mathrm{X} 4$ is 0 (zero), the value of dependent variable is 7.671. Variable Brand Image (X1) has the value of regression coefficient in plus direction $(+)$ of 0.185 . If Brand Image increased $1 \%$, it would be followed by the increase in buying decisions as much as 0.185. Variable Brand Trust (X2) has the value of regression coefficient in plus direction (+) of 0.375 meaning that if Brand Trust increases as much as $1 \%$, it would be followed by the increase of buying decision as much as 0.375. Variable Reference Group (X3) has the value of regression coefficient in plus direction (+) as much 0.218 , in other words, if Reference Group increases as much as $1 \%$, it would be followed by the increase of buying decision as much as 0.375 . 
Based on the table and the explanation above, it can be explained that the result of $\mathrm{t}$ test shows as the following. The probability value of regression coefficient X1 is 0.019 . The value is less $5 \%$ and the direction of its regression coefficient is in accordance with the expectation. Therefore, statistically, $\mathrm{H} 1$ which brand image has positive effect on buying decision of sneakers is accepted. The probability value of regression coefficient X2 is 0.0 . The value is less than $5 \%$ and the direction of its regression coefficient is in accordance with the expectation. Therefore, statistically, $\mathrm{H} 2$ which Brand Trust has positive effect on buying decision of sneakers is accepted. The probability value of regression coefficient X3 is 0.017 . The value is less than $5 \%$ and its regression coefficient is in accordance with the expectation. Therefore, statistically, H3 which Reference Group has positive effect on buying decision of sneakers is accepted.

H1 stating that Brand Image has positive effect on buying decision of sneakers is accepted. Therefore, the study result shows the higher image of a brand, the higher buying decision of sneakers would be. Consumers would be more interested in sneakers brand that has the brand image that is good, famous, and so on because they feel self satisfaction when getting the product. The result of this study supports the studies done by Sulistyawati (2011, Suciningtyas (2012) and Romadhoni (2015). It is just that the objects of study done are different.

$\mathrm{H} 2$ stating that Brand Trust has a positive effect on the buying decision of sneakers is accepted. Therefore, the study results show that consumers more trust in the product, such as trust in product quality, brand reputation, and others, would tend to make belief in sneakers buying decisions. When consumers and users believe in a brand chosen, they will decide and end with buyer satisfaction. The result of this study supports the studies done by Arista \& Astuti (2011), Pratama, Nugraha \& Suryoko (2014), and Adiwidjaja \& Tarigan (2017). It is just that the objects of a study done are different.

H3 stating that Reference Group has a positive effect on the buying decision of sneakers is supported (accepted). Therefore, the study result shows that the more effect of reference groups in buying process, it would tend to affect buying sneakers more. Before deciding to buy a product, if the consumers get influenced by reference groups such as friends, community, or idols, they would get more belief in choosing sneaker products. This study supports the studies from Fitriyah (2013) and Anoraga \& Iriani (2014) that the reference group positively affects buying decisions. It is just that the studied objects are different. Fitriyah (2013) studied handmade batik and Anoraga \& Iriani (2014) on smartphone product.

Based on the data analysis result above, the discussion on hypothesis testing is as the following. The determination coefficient test is for measuring how much the ability of regression model in explaining the effect of independent variable on dependent variable. In Table 2 above, it can be seen that Adjusted R Square is 0.415 . It means that $41.5 \%$ of sneakers buying decision can be explained by other variables that are not studied in this study. The table shows that $F$ count of 30.365 with a probability value of $F$ of 0.00 . Because its probability is less than 0.05 , the regression model can be used to predict buying decision sneakers with the independent variables of Brand Image, Brand Trust, and Reference Group. 


\section{Conclusion}

From the collected data of respondents, the sneakers are from brands Vans, Converse, Nike, Sketchers, Reebok, Macbeth, and Compass. Vans users were on the largest percentage, which was $30 \%$. The users of Converse and Nike were in second place, with a rate of $22 \%$. Based on the demographic analysis result, most respondents were male, aged 20-25 years old, and they were students. Based on the descriptive analysis, respondents generally tended to state agree that products of sneakers have brand image, brand trust, and reference group.

Moreover, respondents also tended to agree to buy sneakers. Then, based on the result of hypothesis testing and discussion, the findings of this study are the following. First, Brand Image has a significant positive effect on purchasing decisions for sneakers. Second, Brand Trust has a significant positive effect on purchasing decisions for sneakers. The Reference Group has a significant positive effect on purchasing decisions for sneakers.

The implications of the findings of this study are as follows. Because brand image, brand trust, and reference groups have an influence on the purchasing decisions of its consumers, sneaker product makers, distributors, and retailers need to pay attention to these three variables and their effects on purchasing decisions for sneakers. They need to establish a good relationship with the reference group so that there is an emotional connection and get their feedback. With this feedback, the manufacture and supply of sneakers can always be adjusted to the expectations of the reference group members and their customers.

\section{Limitation and study forward}

The limitations of this study are as the following. The testing involved only 3 factors, while generally, buying decisions is often affected by some other factors, such as price, taste, and others. Moreover, the questionnaire distribution also must focus on consumers who have purchased sneakers so that they are more segmented and the study result can be in accordance with the objective.

Suggestions for the next study are as the following. The researcher expected that this study results could be a reference for the next researchers in marketing, especially for sneakers, and support other researchers. The researcher also expected the next studies to add some other factors that have not been studied in this study, such as the effect of price, taste, brand awareness, and others.

\section{References}

Adiwidjaja, A. J. \& Tarigan, Z. H. (2017). Pengaruh brand image dan brand trust terhadap keputusan pembelian sepatu converse. Working paper, Universitas Kristen Petra, Surabaya.

Ain, N. \& Ratnasari, R. T. (2015). Pengaruh citra merek melalui sikap konsumen terhadap niat beli ulang pada produk busana muslim Zoya di Surabaya. Jurnal Ekonomi Syariah Teori dan Terapan (JESTT), 2(7), 553-569.

Amirullah. (2002). Perilaku konsumen. Jakarta: Penerbit Graha Ilmu.

Anoraga, B. J. \& Iriani, S. S. (2014). Pengaruh gaya hidup dan kelompok acuan terhadap keputusan pembelian smartphone merek Samsung Galaxy. Working paper, Universitas Negeri Surabaya. 
Arista, E. D. and Astuti, S. R. T. (2011). Analisis pengaruh iklan, kepercayaan merek,dan citra merek terhadap minat beli konsumen. Jurnal Aset, 13(1), 37-45.

Biel, A. L. (1992). How brand images drives brand equity. Journal of Advertising Research, 32(6), 6-12.

Delgado-Ballester, E. \& Munuera-Alemán, J.L. (2001). Brand trust in the context of consumer loyalty. European Journal of Marketing, 35(11/12), 1238-1258

Delgado-Ballester, E., Munuera-Aleman, J. L., \& Yague-Guillen, M. J. ( 2003). Development and validation of a brand trust scale. International Journal of Market Research 45, Vol. 1, 35-54.

Engel, J. F., Roger D. B. \& Paul, W. M. (1995). Consumer Behavior, $8^{\text {th }}$, Fort Worth: Dryden Press.

Fakhrunnisa, M. (2016). Gaya busana sebagai media pembuktiaan identitas musik white shoes and the couple company. e-journal "Acta Diurna”, 5(1), 1-6.

Fitriyah, N. (2013). Pengaruh kelompok acuan dan keluarga terhadap keputusan pembelian batik tulis jetis pada Toko Amri Jaya Sidoarjo. Jurnal Pendidikan Tata Niaga, 1 (3).

Ghozali, I. (2011). Aplikasi analisis multivariate dengan program SPSS. Semarang: Badan Penerbit Universitas Diponegoro.

Hasibuan, L. (2018). Artikel peminat sneakers di Indonesia naik 70\%. Jakarta: CNBC Indonesia. https://www.cnbcindonesia.com

Kotler, P. \& Keller, K. L. (2006). Marketing management. 12th, London: Prentice Hall.

Kotler, Ph. (2003). Marketing management, $11^{\text {th }}$. Englewood Cliffs, NJ.: Prentice-Hall.

Lau, G. T. \& Lee, S.H. (1999). Consumers' trust in a brand and the link to brand loyalty. Journal of Market-Focused Management, 4, 341-370.

Nainggolan, I. (2018). Artikel in-depth: Minat belanja dipengaruhi fashion influencer instagram, Ini faktanya!. Jakarta: Buka Review. https://review.bukalapak.com

Pratama, D.P., Nugraha, H. S., \& Suryoko, S. (2014). Pengaruh treat emotions, kepercayaan merek dan harga terhadap keputusan pembelian produk susu anlene actifit. Jurnal Administrasii Bisnis, 3(1), 1-10.

Rizan, M. (2012). Pengaruh brand image dan brand trust terhadap brand loyalty the botol Sosro. Jurnal Riset Manajemen Sains Indonesia (JRMSI), 3(1), 1-17

Romadhoni, M. (2015). Pengaruh citra merek (brand image) terhadap pengambilan keputusan pembelian sepatu nike pada mahasiswa FIK UNY. Journal Student UNY, Yogyakarta.

Susanti, A. (2018). Artikel AZA 6, seri terbaru sepatu basket yang dipakai Presiden Jokowi ludes dipesan. Tribun Jatim. Jawa Timur. https://jatim.tribunnews.com

Setiadi, G. (2013). Pengaruh kualitas jasa dan bauran promosi terhadap keputusan pembelian konsumen pada perusahaan pemasangan batu hias di PD. Alam Indah Pasteur Bandung. Working paper, Universitas Widyatama, Bandung.

Schiffman, L.G \& Kanuk, L.L. (2004). Perilaku konsumen. Edisi ketujuh. Jakarta:Penerbit Indeks.

Simamora, B. 2005. Analisis multivariat pemasaran. Jakarta: Penerbita PT Gramedia Pustaka Utama.

Sumarwan, U. (2014). Perilaku konsumen: Teori dan penerapan dalam pemasaran. Edisi kedua. Bogor: Ghalia Indonesia. 
Suciningtyas, W. (2012). Pengaruh brand awareness, brand image dan media communication terhadap keputusan pembelian. Management Analysis Journal, 1(1).

Sugiyono. (2013). Metode penelitian pendidikan. Bandung: Alfabeta.

Sulistyawati, P. (2011). Analisis pengaruh citra merek dan kualitas produk terhadap keputusan pembelian laptop merek Acer di Semarang. Working Paper, Fakultas Ekonomi Manajemen Universitas Diponegoro Semarang. 